\title{
Litterære karakterer mellem tekstualitet og mimesis ${ }^{1}$
}

Der gives grundlæggende to forskellige synspunkter på hvad litterære karakterer, dvs. menneskelige væsener som de fremstilles i en litterær tekst, er for nogle størrelser.

Det første synspunkt hævder, at litterære karakterer er tekstuelle konstruktioner; inden for fiktionens rammer gælder de for at være menneskelige væsener, men de er »lavet af« tekst og derfor er deres forbindelse med og afbildningsværdi i forhold til rigtige mennesker ikke-eksisterende eller udelukkende konventionelt betinget: det er en del af den kontrakt vi indgår med forfatteren, at hans litterære karakterer skal gælde for mennesker.

Det andet synspunkt hævder, at litterære karakterer repræsenterer eller efterligner virkelige mennesker. Når vi analyserer og fortolker en litterær tekst har vi derfor lov til at forholde os til personerne, som om de var virkelige og ikke lavet af tekst; vi kan anstille psykologiske, eksistentielle eller common sense agtige betragtninger over deres adfærd og motiver, som om de var mennesker vi mødte.

Vi kan kalde det første synspunkt for tekstuelt og det andet for mimetisk. Man kan mene, at vi her har formuleret to ekstreme synspunkter, der ligger i hver sin ende af et kontinuum, og at sandheden nok ligger »et sted midt imellem«. Det kan vise sig at være tilfældet. Jeg vil i det følgende måle dem mod hinanden og skal forudskikke at jeg selv har en del godhed for mimetismen uden at jeg dog vil frakende tekstualismen vigtige indsigter.

1. Nærværende artikel er en omarbejdet udgave af et engelsksproget oplæg "Literary Characters and Gestalt Theory", som blev holdt i 1994 på et seminar om Gestaltteori, arrangeret af Center for Urbanitet og Æstetik, Københavns Universitet. På daværende tidspunkt var jeg ikke stødt på andre i dansk sammenhæng, der systematisk beskæftigede sig med litterær karakterologi. Siden dengang har den karakterologiske diskussion i dansk litteraturvidenskab fået en både meget bred og fint udarbejdet platform at udfolde sig på med Per Krogh Hansens ph.d.-afhandling om emnet, som jeg havde den fornøjelse at være censor på. Afhandlingen kom som bog forrige år: Per Krogh Hansen: Karakterens rolle. Aspekter af en littercer karakterologi, Kbh. 2000. 
Men hvorfor - kan den rendyrkede tekstualist spørge - er det overhovedet interessant eller relevant at stille spørgsmålet om forbindelsen mellem litterære karakterer og virkelige karakterer, mellem homo sapiens og homo fictus, som forfatteren E. M. Forster en gang har kaldt dem.

Det er det i første omgang p.g.a. loeseoplevelsen. Når vi læser en fiktiv tekst, giver vi spontant karakterne ontologisk kredit - vi lever med dem, føler med dem, lider med dem, interesserer os for deres skæbne som om de var levende væsener, virkelige personer. Det er ikke noget vi behøver beslutte os for eller tage os sammen til. Tværtimod er denne ontologiske indrømmelse en forudsætning for at vi overhovedet kan læse, nyde og forstå fiktion eller fortællende litteratur.

Som professionelle læsere, bedømmere og fortolkere af litteratur kan vi imidlertid ikke blive stående på denne spontane forudsætning. Dertil er den blevet for voldsomt problematiseret i moderne litteraturvidenskab. Den uskrømtede menneskelige interesse for de litterære personer kan derfor uden videre tages som et kendetegn på den uskolede læser, f.eks. i skikkelse af den unge og umodne litteraturstuderende. Denne ungdomssynd vil sædvanligvis blive uddrevet af den erfarne lærer, som vil forklare følgende: ‘Du kan ikke behandle personen som om han var levende på samme måde som du og jeg. Du kan ikke bare påføre ham dine egne frie spekulationer; han er en konstruktion i teksten, gjort af tekst, og man kan derfor kun have med ham at gøre gennem teksten.'

Uskolede og umiddelbare læsere er mimetister. Skolede og professionelle læsere er tekstualister. Og så kan det alligevel ikke stilles op på helt denne måde. Den professionelle læser kan nemlig aldrig lade den spontane læsning bag sig. Han kan formodentlig slet ikke læse en fiktionstekst uden at gøre det - periodevis - spontant, umiddelbart, medlevende. En tekst åbner sig ikke for én, hvis man ikke åbner sig for den. Man kan f.eks. ikke på samme tid føle med en karakter og analysere, hvordan han/hun er lavet; det kan godt være, at man kan gøre begge dele indenfor et minut eller mindre, men det er i så fald at forstå som en penduleren mellem to attituder overfor teksten, en stadig bytten ét blik ud med et andet blik. Man kan derfor ikke opstille en absolut og gensidigt eksklusiv modsætning mellem en naiv og en videnskabelig læsning.

Når vi således alle - på et eller andet niveau - er mimetister, bør den professionelle litteraturlæsning også tage højde for det niveau - læseoplevelsen hvor vi giver ontologiske indrømmelser til karaktererne. Om ikke andet må den betragte det som et ejendommeligt og forklaringskrævende forhold. I modsat fald må den slet og ret hævde, at enhver spontan læsning altid er en miskendelse af teksten, som bør substitueres eller efterfølges af den professionelle læsnings erkendelse. Lystlæsning og professionel læsning vil derfor 
få uendeligt lidt med hinanden at gøre. Det vil efter min mening være en kontra-intuitiv position at indtage.

En analytisk læsning bør snarere kunne gribe tilbage til, explicitere og kvalificere læseoplevelsen udfra en forventning om at denne allerede havde en eller anden præ-refleksiv fænomenologisk-analytisk gehalt i forhold til teksten. For det er jo ikke sådan, at min læseoplevelse er »min« i privatpsykologisk eller anden uvedkommende forstand. Man bør derfor heller ikke tænke forholdet mellem spontan og analytisk læsning som en temporal succession, hvor den umiddelbare læsning er den førstegangslæsning, man én gang for alle må lægge bag sig som en fejlkilde eller en privatsag for at kunne påbegynde en egentlig analyse eller fortolkning.

Den litterære karakterologi er et af de hængsler hvorom forholdet mellem den spontane og den skolede læsning må dreje, fordi karaktererne traditionelt er det element i en tekst, der kalder på vores indlevelse.

$\mathrm{Nu}$ har interessen for de litterære karakterer ikke altid været ugleset i litteraturvidenskaben. Litteraturforskere fra tidligere tider fortolkede gladeligt løs på de fiktive personer, og som regel på en usystematisk og common sense-agtig måde, der har virket yderst naiv på en senere tids mere videnskabeligt avancerede ånder. Modsætningen mellem mimetisme og tekstualitet kan derfor også opstilles som en faghistorisk udviklingslinie, hvor det 19. århundredes lidt diffuse moralske, psykologiske og humanistiske tilgang til litteraturen afløses af det 20. århundredes mere formelle og tekniske tilgange. Brutalt udtrykt var selv de skolede læsere naive i gamle dage.

I vore dage har denne »menneskelige interesse« i litteraturen mest overlevet i dagbladenes anmeldelser af fiktionsprosa. Her kan man jævnligt iagttage hvorledes en æstetisk bedømmelse af en roman bl.a. afhænger af en »evaluering« af romanens karakterer: bliver de levende for læseren eller minder de mest af alt om tegneseriefigurer eller marionetdukker? En litterær dagbladsanmeldelse er i sin natur en meget kort litteraturanalyse, hvor den bagvedliggende litteraturteori kun kan være impliceret, og sådanne karakterologiske vurderinger har derfor aldrig plads til at blive mere udførligt begrundet. Og det er nok meget heldigt, for idet karakterologien har været eksileret fra litteraturvidenskaben i nyere tid, kan det være svært at forestille sig hvilke teoretiske kriterier og analytiske redskaber en sådan vurdering egentlig har at gribe til, hvis den ikke vil lade sig nøje med sin uudgrundelige følelse af at sådan er det nu engang fat.

Mit synspunkt er, at litteraturteorien og litteraturanalysen bliver alvorligt amputeret, hvis den kapper forbindelsen til sine "præ-videnskabelige» rødder, eksempelvis vores levende interesse i fiktive personers egenskaber og skæbne. Ikke blot sådan forstået, at den anstændigvis bør nære en vis respekt både for sin egen disciplins fortid og for de almindelige læsende 
mennesker udenfor formskærerlauget. Nej, den bliver til dårligere litteraturteori og litteraturanalyse af at ignorere karakterologien, både forstået som de litterære karakterers analytik - hvordan er de »lavet« og hvordan skal de analyseres? - og de litterære karakterers ontologi - hvilken eksistensform har de sammenlignet med virkelige mennesker? ${ }^{2}$

Den mimetiske position er naturligt bundet til en opfattelse af litteratur, der lægger vægt på litteratur som et erkendelsesredskab-noget der kan gøre os klogere på menneskenes børn, på tilværelsen, på virkeligheden. Hvis vi i en tekst søger "menneskekundskab« eller et eller andet eksistentielt udbytte, kan vi ikke gøre det uden den ontologiske indrømmelse til karaktererne. Hvordan skulle vi kunne uddrage menneskekundskab hvis der ikke er mennesker på færde? Hvordan skal vi kunne hente en eksistentiel erkendelse, hvis de litterære væsener ikke eksisterer på betingelser, der - i hvert fald til en vis grad - er sammenlignelige med vores egne? Den eksistentielle interesse i litteraturen er så at sige den reflekterede udgave af den spontane læsnings ontologiske indrømmelse til karaktererne. En indrømmelse af anden grad, forsåvidt det nu ikke er karakterernes konkrete gøren og laden, der interesserer, men mere hvad denne gøren og laden fortæller os på et eksemplarisk plan.

Tanken om litteraturen som erkendelsesredskab findes i litteraturvidenskabelig sammenhæng overvejende i fænomenologisk regi. Man kan f.eks. nævne Paul Ricoeur og Milan Kundera. I dansk sammenhæng gives der også en velfunderet (livs)filosofisk tradition for at inddrage litteraturen som erkendelsesmedium: K. E. Løgstrup, Mogens Pahuus og Niels Thomassen kan nævnes her. ${ }^{3}$

Mit ærinde i denne artikel er at give et teoretisk bidrag til den litterære karakterologi - et bidrag, der kan styrke synet på litteraturen som et legitimt erkendelsesredskab. I det følgende vil jeg besigtige forskellige bud på de litterære karakterers analytik og ontologi med henblik på at undersøge om mellempositionen mellem tekstualitet og mimetisme gives - og hvis ikke, hvad vej pendulet så svinger. Jeg har valgt ikke at opsøge repræsentanter for bestemte litteraturvidenskabelige skoler, f.eks. fænomenologien, men i stedet folk, der med vidt forskellig indgang har sagt noget efter min mening væsentligt om litterær karakterologi.

2. Jeg har en principiel uenighed med Per Krogh Hansen hvad det sidste aspekt angår. Han erklærer sig som formalist og ønsker blot at supplere den formalistiske litteraturanalyse med det karakterologiske niveau. Den »præ-videnskabelige« interesse i karaktererne bliver afskrevet som »humanisme« (eller som en spontan læserattitude som vi alle deler, men som ikke har nogle analytiske eller teoretiske konsekvenser). Karakterens ontologiske problematik vil således for ham kunne opløses i karakterens analytiske problematik. 
Først gælder det E. M. Forster - den engelske skønlitterære forfatter, der bl.a. er kendt for romanerne Room with a View og Howards End. I 1927 funderede han i Aspects of the Novel over forskellige aspekter ved romankunsten, bl. a. de litterære karakterer, som han inddelte i to slags: flade og runde karakterer. Det lyder på én gang enkelt og suggestivt, og Forsters begrebspar er da også blevet et uomgængeligt referencepunkt for al senere karakterologi. Vi vil se, at det dog ikke er helt så ligetil som det kan lyde, og man kan have Forster mistænkt for ikke at have fuld klarhed over sin egen anvendelse af de begreber, han søsætter. Det skyldes nok, at han er en litterær praktiker, der taler ud fra megen læse- og skriveerfaring snarere end ud fra et vandtæt begrebsapparat. Men erfaren mand er god at gæste i disse sager, også selvom han ikke er en systematiker, og jeg finder det særligt relevant at betragte Forster som kongevejen til karakterologien, fordi han behandler det analytiske og det ontologiske niveau i samme bevægelse.

I anden del af artiklen vil jeg behandle Seymour Chatman, som til trods for at han egentlig er ekspert i stilistik, retorik og narrative strukturer, i sin bog Story and Discourse fra 1978 demonstrerer et åbent sind overfor karakterproblemet. Hvor Forster taler mere intuitivt om sagen, i sin egenskab af forfatter, prøver Chatman at tilnærme sig problemet ad teoretisk og analytisk vej - på den moderne litteraturvidenskabs skolede præmisser. Det volder ham visse problemer, og de er ganske illustrative, fordi de viser hvor svært det kan være at ramme et balancepunkt mellem tekstualitet og mimesis.

Endelig vil jeg i tredje del af artiklen inddrage gestaltteorien, nærmere bestemt Solomon Asch og et lille uddrag af hans Social Psychology fra 1953. Det vil jeg gøre, fordi Asch her stiller sig spørgsmålet om hvordan vi opfatter - konstruerer, om man vil - rigtige mennesker, når vi møder dem i det

3. Et karakterisk eksempel på den professionelle litterats noget forbeholdne, omend i dette tilfælde på overfladen vældigt venlige, attitude overfor denne tradition kan vi finde i professor Thomas Bredsdorffs anmeldelse af Thomassens nyligt udkomne bog Ulykke og lykke, Kbh. 2001: "Som Løgstrup ynder Thomassen at tage en scene eller et handlingsreferat fra en film eller en roman og så udlægge dem med henblik på 'det, man kalder livet'. Her er lidt Truffaut og Ingmar Bergman, lidt Sønderby og Graham Greene, meget Paul Auster, et stænk Henrik Nordbrandt - men han er lige ved at være for orientalsk, og så falder han udenfor - mens Schade og Bjørnvig er klart indenfor. Og det er også den ukuelige Barbara, både på film og på bog. (...) man er i godt selskab, med en dannet og tænksom læser, der bruger skønlitteraturen som en praktisk genvej til livet. Det er ikke en form for tekstlæsning, der står højt i kurs blandt litterater, men det kan jo være deres fejl, og monopol på, hvordan man skal læse digte og romaner, har vi jo heldigvis ikke. Man kan ikke sige, at Niels Thomassen vækker til modsigelse, for han siger sjældent noget, der kan modsiges. Men han vækker til eftertanke og minder om noget ekstremt vigtigt: at litteraturen ikke er litteraternes. Den tilhører enhver, der gider læse og udlægge - og indlægge. Det er det, der er det fantastiske ved litteratur.«(Citeret fra Politikens anmeldelse 6. oktober 2001.) 
virkelige liv. Gennem hans undersøgelse vil vi derfor blive i stand til at se forskellen mellem vores opfattelse/konstruktion af virkelige mennesker og mennesker i litteraturen. Og jeg mener ikke, at man kan bedrive litterær karakterologi uden - i hvert fald indimellem - at være nødt til at referere eller rekurrere til ikke-litterær karakterologi. ${ }^{4}$

\section{E. M. Forsters flade og runde karakterer}

Inden E. M. Forster i sin tekst når frem til det berømte skel mellem runde og flade karakterer, gør han sig betragtninger over artsforskellen på homo sapiens og homo fictus. Han indleder med andre ord på det ontologiske niveau: hvad kan man, i splendid abstraktion fra specifikke litterære tekster, sige om de litterære karakterers måde at vaere til på til forskel fra rigtige mennesker?

Homo fictus bruger ikke helt så meget tid på søvn og fødeindtagelse som homo sapiens, men så meget mere på kærlighed og i det hele taget er fiktive mennesker langt mere optagede af og sensitive overfor hinanden end virkelige mennesker. Litterære karakterer lever således generelt mindre trivielle og rutineprægede liv end virkelige karakterer; den litterære fiktion tilbyder et idealiseret eller dramatiseret billede af menneskelivet. Sådan må vi udlægge Forsters første distinktion, og den er forsåvidt ganske simpel. Vi hører generelt ikke meget om måltider og toiletbesøg i litteraturen med mindre det netop gøres til en pointe (f.eks. Blooms stolegang i Ulysses) og det kan det kun blive ved at afvige i forhold til normen. Det er også et spørgsmål om informationsøkonomi. Teksten fortæller os det væsentlige og ikke det vi kan sige os selv.

Den helt afgørende artsforskel er dog ifølge Forster, at vi principielt kan vide alt om fiktive personer, de er definitive, forklarlige, fordi den, der fortæller dem og den, der har skabt dem, er den samme instans. Hvorimod vor viden om virkelige mennesker, endog vore nærmeste, ofte kan være stykkevist og delt. Man kan bemærke, at denne fundering af artsforskellen er mere formel og principiel end den første: der er her tale om en absolut arts-

4. Her ligger min anden principielle uenighed med Per Krogh Hansen. »Virkelig« karakterologi bliver kun yderst perifert berørt i Karakterens rolle og da på en lidt ubekymret måde, der lader ane, at det slet ikke betragtes som noget problem, f.eks. s. 113: "..karakterer, der er hele mennesker [eksisterer] ikke. Karakteren vil altid differentiere sig fra det virkelige menneske og være mere konstruktion end rekonstruktion, hvilket de foregående definitioner har vist«. Problemet er, at det aldrig ekspliciteres nærmere hvad der skal forstås ved begreber som f.eks. "hele mennesker« og »det virkelige menneske« - hvordan de defineres og hvordan de er givet for os - og dermed bliver udsagnene postulatoriske. Det forbliver tavst underforstået, hvad det er litterære karakterer sammenlignes med og stilles op imod. 
barriere, der ikke kan overskrides, og den er afhængig af det litteraturen formelt gør ved sine karakterer. ${ }^{5}$

Forster stiller sig selv spørgsmålet om hvornår litterære karakterer virker mest virkelige på os læsere. I henhold til artsskellet mellem homo sapiens og homo fictus kunne man jo formode, at spørgsmålet betyder, hvornår de litterære karakterer mest virker som nogle der ligner os (dvs. empirisk virkelige), men her twistes diskussionen lidt: de virker mest virkelige, når de virker overbevisende på os læsere, og det gør de når de er mest i overensstemmelse med lovene, ikke i virkeligheden, men i det kunstværk de optræder i. Altså de mest virkelige er de kunstnerisk mest vellykkede. Forster antyder selv, at dette er et meget fornuftigt svar, som også er en anelse konventionelt og derfor kan findes i enhver litterær håndbog på hans tid.

Han efterspørger da selv et mindre æstetisk og mere psykologisk svar og griber her tilbage til sin tidligere pointe: litterære karakterer virker virkelige, når de er forklarlige. $\mathrm{Og}$ det er måske også blot en bedre og mere præcis måde at sige det samme på: litterære karakterer er mest (litterært) virkelige, når de er mest (empirisk) uvirkelige; kunstnerisk virkelighed og empirisk virkelighed er nemlig ikke det samme, i tilfældet definitiv forklarlighed af en person udelukker de ligefrem hinanden, hvilket ikke er tilfældet i de manglende toiletbesøg, som forfatteren måske bare undlader at berette for os.

Som Forster selv bemærker: hvis han og hans tilhørere enes om at Daniel Defoes kvindelige karakter Moll Flanders er en overbevisende person - og han da pludselig råber og siger: se, der er hun, dernede, det er Moll! - så vil alle spontant vide, at det ikke er sandt og ikke kan være sandt, ikke bare fordi hun er fiktiv - men fordi der ikke kunne gives en sådan person. Hendes troværdighed er så at sige ikke af denne verden, fordi vi aldrig kommer til at kende nogen virkelige personer som godt som vi kan komme til at kende fiktive personer, fordi de sidstnævntes indre og hemmelige liv i princippet er tilgængeligt for os.

Det kan synes som om Forster som konklusion på sine ontologiske overvejelser opretter en uoverkommelig ontologisk kløft mellem litterære og virkelige karakterer. $\mathrm{Og}$ at han, for at bruge vores vokabularium, har et mere

5. Nogle vil måske indvende, at det langtfra er alle litterære karakterer der fremviser »transparent minds" (Dorrit Cohn), og at denne gennemsigtighed og alvidenhed er betinget af bestemte fortælleforhold og synsvinkelteknikker. Men Forster rammes ikke uden videre af en sådan kritik. Det afgørende for ham er ikke, at vi får karaktererne totalt forklaret og gennemlyst, men at vi får følelsen af at det principielt godt kunne lade sig gøre: »...han (forfatteren,ngh) vil give os fornemmelsen af at selvom karakteren ikke er blevet forklaret, er den forklarlig, og derved give os fornemmelsen af en virkelighed, vi aldrig ville kunne få i det virkelige liv«, Aspects of the Novel (i det efterfølgende forkortet $A N$ ), p. 69, Harmondsworth 2000 , min oversættelse, NGH. 
tekstuelt end mimetisk syn på karaktererne. Med den ironiske drejning at jo mere mimetiske (virkelige) karaktererne forekommer os, jo mere tekstuelle (virkelige efter kunstneriske kriterier) er de faktisk. Og dermed vil hele det skel vi har oprettet mellem den tekstuelle og den mimetiske tilgang forstået som to yderpunkter $\mathrm{i}$ et kontinuum falde sammen. Vi vil vende tilbage til dette. Nu skal vi se hvordan han introducerer sit berømte skel mellem flade og runde karakterer:

»Vi kan dele karakterer op i flade og runde. I det 17. århundrede blev flade karakterer kaldt »humours«, og de kaldes nogle gange for typer og andre gange for karikaturer. I deres reneste form er de bygget op omkring én enkelt idé; når der er mere end én faktor til stede i dem, får vi begyndelsen af kurven mod det runde« $(A N$, p. 73).

Forster bruger altså flad og rund som metaforer for henholdsvis den simple karakter og den komplekse, højt organiserede karakter. En enkelt sætning er nok til at indfange den flade karakter. Nogle karakterer siger denne sætning selv, som f.eks. mrs. Micawber i Dickens' David Copperfield: „Jeg vil aldrig forlade mr. Micawber«. Dette er hendes stadige replik i romanen. Og hendes person kan faktisk opsummeres i denne ene sætning, siger Forster. I dette tilfælde indføres sætningen altså faktisk af forfatteren. Men man kan også forestille sig en »uudtalt« sætning, som er et resultat af læserens opfattelse af karakteren.

Flade karakterer virker stabiliserende på en tekst - når de dukker op efter at have været fraværende en tid, bringer de automatisk (deres) helt bestemte træk og signaler med sig. En tekst kan godt bestå af udelukkende flade karakterer; det vil ofte være tilfældet i komedien og i den folkelige litteratur. Det er til gengæld mere usandsynligt at en fiktiv verden skulle kunne bebos af udelukkende runde karakterer. Hvis personer skal kunne agere med hinanden i en fortælling, må nogle af dem nødvendigvis være mere skematiserede end andre. Det gælder selv for Dostojevski, selvom man godt kan få på fornemmelsen i nogle af hans romaner, at ambitionen er at konstruere en fiktiv verden med udelukkende runde karakterer - og derfor er nogle af romanerne så vældig store, dramatiske, løse i fugerne og fulde af dialoger.

Vi må tolke Forster sådan, at betegnelsen flade karakterer dækker allehånde stereotyper og karikaturer i litteraturen, og at formentlig langt de fleste bipersoner i verdenslitteraturen også er flade, forsåvidt vi kun kender dem gennem et eller nogle få aspekter. Jo mere en karakter er destineret til at spille en bestemt rolle, udfylde en bestemt funktion i en tekst, jo mere flad er han, mens verdenslitteraturens hovedpersoner må gælde for 
altovervejende runde. En rund person har brug for flade personer omkring sig til at modsige, balancere og perspektivere nogle af hans egne isolerede egenskaber. Men interaktionen mellem flade personer er også essentiel for litteraturen, jvf. det klassiske modsætninger mødes princip: Don Quixote og Sancho Panza, Sherlock Holmes og dr. Watson. Relationen mellem de to sidstnævnte kan faktisk opsummeres i en enkelt sætning: „Elementary, dr. Watson«!

Det kunne være fristende også at udlægge Forster således at flade og runde karakterer stort set er det samme som bipersoner og hovedpersoner. En hovedperson er jo den vi kender bedst og kommer mest rundt om, mens bipersoner kun udfylder visse aspekter i fortællingen. Men det skal tilsyneladende ikke forstås på denne måde. Forster strør i hvert fald kriterierne omkring sig på en betydeligt mere løs måde. Det hedder f.eks.at næsten alle personer hos Dickens er flade, mens næsten alle hos Jane Austen er runde. Det sidste gælder også for personerne hos Dostojevski og Tolstoj. Det karakterologiske begrebspar flad-rund synes dermed løsrevet fra »tekstuelle« kriterier: om man er flad eller rund har ikke nødvendigvis noget at gøre med hvor meget man optræder i en tekst eller hvilken funktion man har i tekstens økonomi. Det virker nærmest som et uafhængigt psykologisk kriterium, man kan bruge på personerne én efter én (»næsten alle hos Dickens...»)

Andre steder lægger han dog op til, at karakterer ikke på denne måde kan tages ud af deres sammenhæng, fordi de i deres givne tekst stækker og begrænser hinanden. Moll Flanders beskrives som et stort træ man kan gå rundt om og besigtige, fordi hun er alt og får frit spil i den bog, hun er den særdeles dominerende karakter. I en Jane Austen-roman beskrives karakterne derimod som interdependente, de kan ikke for vores forestilling spredes vilkårligt ud i andre tekster, uden hinanden. Forsters synspunkt forekommer her igen at være tekstualistisk. Han siger også at vi kan have sværere ved at huske de runde karakterer, fordi de ikke kan opsummeres i en enkelt sætning, har mange facetter og ligesom er groet sammen med bestemte scener, de har ageret i.

Dette synspunkt kan virke overraskende, fordi vi spontant ville mene at de runde karakterer er de store og vigtige personligheder som burde stå udpræget stærkt i erindringen. Men det passer godt sammen med at Forster straks efter kaster sig ud i en hyldest til flade karakterer, specielt som de optræder hos Dickens.

»Næsten alle mennesker hos Dickens er flade (..) Næsten alle kan de opsummeres i en enkelt sætning, og alligevel er der denne vidunderlige følelse af menneskelig dybde. Måske er det den umådelige vitalitet hos Dickens selv, der får alle hans karakterer til at vibrere en smule, således 
at de låner hans liv og synes at have deres eget. Det er en tryllekunst; I ethvert givet øjeblik vil vi kunne se på mr. Pickwick fra siden og opdage, at han ikke er tykkere end en grammofonplade. Vi opnår bare aldrig dette syn fra siden. Mr. Pickwick er alt for behændig og veltrænet. Han kan altid give indtryk af at veje noget (..). En del af Dickens's geni er, at selvom han bruger typer og karikaturer, folk som vi genkender lige i det øjeblik, de igen gør deres entré, så opnår han alligevel virkninger, som ikke er mekaniske og en vision af menneskelighed, som ikke er hul. De, der ikke bryder sig om Dickens, har en god sag. Han burde være dårlig. Men han er faktisk en af vore største forfattere, og hans enorme succes med typer antyder, at der kan være mere ved fladhed end de strengere blandt kritikerne vil medgive« $(A N$, p. 76$)$.

At tale om at Dickens' figurer låner liv af deres skaber og derved synes at leve deres eget, vibrere og bevæge sig behændigt rundt til trods for at de er flade som grammofonplader, er charmerende formuleringer, men i litteraturteoretisk forstand er det ikke særligt oplysende. Vi er nødt til at gå dybere ind i billedsproget.

Den flade karakter kan ikke iagttages fra forskellige vinkler eller præsentere sig selv på forskellige måder; den er, i princippet, »ikke tykkere end en grammonfonplade«. Den er to-dimensionel, den kan ikke få tilføjet noget ved at vi bevæger os rundt om den. Den runde karakter derimod formår at overraske; den kan fremvise nye egenskaber, hvorved vi får indtryk af at vandre rundt om den og besigtige den fra forskellige vinkler. Det som Forster her beskriver med metaforen »rund « er den temporale succession hvormed vi som læsere bevæger os gennem en tekst og afdækker nye aspekter ved personen, hvorimod den flade vækker genkendelse hver gang den viser sig. ${ }^{6}$ Den runde karakter er altså ikke skematiseret, men akkumulerer stadig nye kvaliteter igennem det narrative forløb - den er kompleks, overraskende, uforudsigelig. En sådan karakter kræver mere arbejde fra læserens side den er ikke et hvilepunkt i teksten. Den runde karakter er dermed mindre autonom; den er vævet ind i tekstens tekstur - de andre karakterer, plottet m.m. er det der leverer materialet til kompleksiteten, hvorfor man ikke kan rive karakteren ud af teksten uden at gøre vold på den. Kompleksitet og

6. De visuelle metaforer snyder, forsåvidt vi ikke "ser« en tekst, men læser den, men hvis vi betænker, at en litterær tekst altid skal konkretiseres af læseren (jvf. Roman Ingarden fænomenologiske litteraturteori), som mere eller mindre detaljerede indre forestillingsbilleder, kan vi godt sige, at »flad« og »rund « giver mening som del af et vokabularium for læserens konkretisering af karaktererne. 
autonomi synes altså ikke at være det samme hos Forster, jvf. også hans bemærkning om at de runde karakterer kan være svære at huske.

Vi når aldrig at »se«, at mr. Pickwick ikke er tykkere end en grammofonplade. Med sin henvisning til Dickens's umådelige vitalitet, som han låner sine egne skabninger, får Forster elegant omgået hele karakterologiens kernespørgsmål: hvad er det præcist, der får en tilfældig samling af ordmasser til at virke som levende mennesker? Det er ikke nok at »lave« karakterne; man skal også have dem til at virke. F.eks. burde, som det fremgår af citatet, flade karakterer som Dickens slet ikke kunne virke så levende og "menneskeligt dybe«. Han burde være en dårlig forfatter. $\mathrm{Og}$ hvad de runde karakterer angår, er det ikke svært at samle en masse forskellige og endda modsatte egenskaber og tilskrive dem til den samme person. Det svære er at få læseren til at acceptere alle disse egenskaber som mulige karaktertræk ved den samme person. Hvor uforudsigelig og kompleks personen end kan synes, skal vi stadig være $\mathrm{i}$ stand til at anerkende ham som værende den samme person, en plausibel karakter. Han skal være levende, være virkelig i modsætning til konstrueret. Og når det, som i tilfældet Dickens, er en større præstation at få flade karakterer til at virke levende, er det fordi konstruktionen her på grund af sin uforskammede simpelhed burde springe mere tydeligt i øjnene. ${ }^{7}$

Det kan undre, at Forster vælger metaforen »rund«til at betegne den komplekse karakter. Bortset fra at den udgør en naturlig modsætning til flad er den ikke et særligt logisk valg. En rund bold forbliver den samme, også når vi kigger på den fra forskellige vinkler - kvaliteten rundhed har noget sluttet og harmonisk over sig, noget er afrundet, siger vi, og det burde derfor ikke være den oplagte metafor for kompleksitet. Hvad »rundheden« egentlig leverer i denne sammenhæng, kunne være følelsen af at personen faktisk forbliver den samme gennem alle udviklingerne. Rundhed ville dermed være

7. Måske har vi ved de flade karakterer et sub-eksempel på paradokset, at det mest tekstuelle (konstruerede) også var det mest mimetiske (levende). Et par voldsomt karikerede personer som den lille Pips søster og svoger i indledningen til Dickens Store forventninger er lette at huske og byder sig også let til for ens konkretiserende forestillingsevne, netop fordi de er så karikerede. Det bør heller ikke falde os svært at huske eller for vort indre blik se de to hegnsarbejdere fra Magnus Mills Sjak nr. 3, fordi de er så parodisk smalspekterede, at selv jeg-fortælleren som kun er en anelse mere kompliceret kan komme til at virke som en dyb uudgrundelighed. Hvor er så egentlig problemet? Jo, det krænker os (inkl. Forster) på det mimetiske plan, at flade karakterer kan virke »levende«; det er som om at ombytte en original med en parodi. Men når virkelige mennesker bliver karikeret og parodieret, bliver de jo også tydeliggjort, evt. udleveret til latteren. Parodien eller karikaturen er et kunstværk, der tager et levende menneske som sit materiale og møblerer lidt om på det. Det er ikke sandheden om det menneske, men det giver et nyt blik på det - det formidler det ved at forstørre eller forvrænge det. På den måde er karikaturer og parodier jo også reelt eksisterende og ikke blot kunstformer - vi kan kun anerkende karikaturen, hvis den er træffende! 
metaforen for at være (at virke) levende, til trods for at man er kompleks, spredt osv. Man går - billedligt talt - ikke ud af en linie og støder på forskellige egenskaber, man går langs med, rundt om, den samme entitet, der da løbende får tilskrevet egenskaber. Rund er dermed en metafor der omfatter både det komplekse og det samlende. Hvor kunststykket i forhold til de flade karakterer er at få dem til at virke livlige, selvom de er - som konstruktionsprincip - mekaniske og hule, må kunststykket i forhold til de runde karakterer være at få dem til at virke sammenhængende, selvom de - som konstruktionsprincip - er komplicerede og fragmentariske.

Forster skriver: „Prøvestenen på en rund karakterer er om den er i stand til at overraske på en overbevisende måde. Hvis den aldrig overrasker, er den flad. Hvis den ikke overbeviser, er den flad men foregiver at være rund. Den runde karakter har livets uberegnelighed over sig - livet som det er på en bogs sider« $(A N$, p. 81).

Forsters anvendelse af sit eget vokabularium er på dette sted en anelse forstyrrende og virker inkohærent. En karakter, der ikke formår at overraske på en overbevisende måde, burde selvfølgelig ikke kunne være "flad « i den tidligere beskrivende betydning af ordet, dvs. simpel og repetetiv. Den er pseudo-rund, usammenhængende, fragmenteret. Men han synes her at bruge »flad« i betydningen uoverbevisende, ikke-levende. I så fald opererer metaforerne på to forskellige niveauer: som metaforer for tekstlige forhold (flad $=$ stabil, repetetiv; rund $=$ uforudsigelig) og som metaforer for det at være mere eller mindre »levende«. ${ }^{8}$

Den overraskende og overbevisende runde karakter har livets uberegnelighed over sig, skriver Forster. At kunne overraske og overbevise på én gang er netop formlen for enhed gennem forandring. Det med livets uberegnelighed lyder meget mimetisk. Dog tilføjer han med det samme: livet indenfor siderne i en bog. Og hvad det så end skal betyde, viser det os tilbage til det tekstuelle.

Det har jo også tidligere heddet sig at de runde karakterer var mere bestemte af plottet og af de andre karakterer. Men det gælder alligevel ikke

8. Forster er ikke den eneste, der anvender et »vitalistisk« kriterium m.h.t. bedømmelse af litterære karakterer. Det gælder også Henry James. Jvf. min artikel »Nærlæsningens grænser. The Making of a Psycho-Nanny? « in Tania Ørum (ed.): Taet på teksten, Kbh. 1994. Jeg går her selv videre ind i en diskussion af den »levende« og uforudsigelige karakter, forstået som uberegnelig. I forhold til de flade karakterer vil der formentlig være noget at hente i denne diskussion, hvis man går vejen om ad en anden vitalist, Henri Bergson, og hans teori om det komiske. De flade og karikerede karakterer har et særlig forbindelse til komedien og det latterlige, fordi de forskyder det levende i retning af det mekaniske. Man kan måske ligefrem sige, at de flade karakterer er »levende«på en anti-vitalistisk måde, mens de runde er det på en vitalistisk måde. Og så kan man måske få udbedret inkonsistensen i Forsters brug af metaforerne på denne måde. 
helt. For Forster siger også om Austens karakterer, at de er "parate til et udvidet liv«. Selvom de, sammenlignet med Dickens’, kan have noget miniature-agtigt over sig, kan man, netop fordi de er højt organiserede, faktisk tænke sig dem i andre scener, andre tekster, andre verdener, udsat for større krav end dem Austens specifikke plot og fiktive verden stiller til dem. Vi har her en genuin tolkning af "rundhed" som autonomi $i$ forhold til det tekstuelle netvork; de runde karakterer må dermed også kunne huskes udover den sammenhæng, de oprindeligt optrådte i!

Dermed undgår Forster ikke som afslutning på den analytiske del at problematisere den absolutte artsgrænse mellem homo fictus og homo sapiens, der blev lagt frem i starten i den ontologiske del. Den runde - og autonome - karakter kan ikke kun være overbevisende og overraskende i forhold til en tekst-intern (kunstnerisk) norm; den må også være det i en eller anden ekstra-tekstuel henseende. Ellers kunne man ikke vurdere, at karakteren er "parat til et udvidet liv«. Men det kan på den anden side ikke betyde, at den runde karakter er overbevisende ud fra det almindelige, virkelige livs empiriske standarder. I henhold til dem kan vi netop ikke møde en Moll Flanders.

Som det gerne skulle fremgå, er Forsters overvejelser meget righoldige, men de er også selvmodsigende; gennem hans tekst bliver begreberne "flad» og »rund « både analyseret og vurderet på modstridende måder, og det forbliver uklart om runde karakterer er autonome eller dependente, ligesom han ikke helt kan bestemme sig for om det mest mimetiske også er det mest tekstuelle, hvilket i givet fald ville få de to yderpunkter, vi har opstillet, til at falde sammen.

\section{Seymour Chatman og karaktertrækkenes paradig- mer}

I sin bog Story and Discourse. Narrative Structure in Fiction and Film ${ }^{9}$ har Seymour Chatman et stort afsnit om de litterære karakterer. Chatman er professor i retorik og hans specialeområde er litterær stilistik, så umiddelbart ville man tro, at han stod relativt fremmed overfor karakterproblematikken. Men tværtimod. Han undrer sig over hvor lidt - både principiel og analytisk - opmærksomhed, man har viet karaktererne i litteraturvidenskaben; enten bliver de helt uproblematiseret set som »mennesker i en bog« eller også bliver de, i traditionen fra Aristoteles” "Poetik « til den russisk formalisme og strukturalisme set som funktioner i plottet, som agenter. Langt de

9. Ithaca, New York 1978. 
fleste moderne karakterer er dog så komplekse, at det ifølge Chatman ville være absurd at betragte dem som rene plotfunktioner - altså som de størrelser, der behøves for at "udløse« de handlinger, der skal udgøre plottet. Chatman er på nippet til at mene, at karakterer måske er vigtigere end plot $\mathrm{i}$ moderne litteratur, fordi vi hylder konventionen om individets unikke karakter til forskel fra konventionen i den tid, hvor eventyr eller ridderromanen var den litterære norm. Men han tager sig dog i det, hvilket er fornuftigt i og med store dele af den efter-realistiske litteratur faktisk ikke synes at interessere sig så meget for karaktererne. ${ }^{10}$ Plot og karakter, mener han i stedet, er lige vigtige og ligebyrdige som emner for refleksion og analyse.

Chatman viser sig også overraskende liberal m.h.t. hvor meget man må spekulere over karaktererne uafhængigt af teksten. Han kan ikke være enig i at Hamlet og Macbeth kun eksisterer som ord på en skreven side. At sige at karakterer blot er fortætninger af ord er lige så absurd som at sige et en statue blot er en fortætning af marmor. Ud fra den information vi får om dem slutter vi os til andre ting og i sidste ende til hvordan de er som karakterer. Selvfølgelig kan der være spørgsmål til karaktererne som er irrelevante eller for langt ude. Der er en grænse, men den bør ikke være for rigidt forvaltet.

Han hylder således karakterens relative autonomi i forhold til det tekstuelle, og naturligt nok går det hånd i hånd med en rekapitulation af de klassiske betragtninger angående denne autonomi: vi kan huske litterære karakterer uden at kunne huske et eneste ord fra den tekst, vi først mødte dem i; de kan blive som venner og livsledsagere for os, vi kan meditere over dem i årevis. Faktisk går Chatman så langt som til at sige, at vi kan have en levende erindring om karaktererne, selv når ethvert af deres (karakter)træk er forduftet for os.

Såvidt sågodt. Selvom man som undertegnede finder positionen sympatisk, må det også siges, at den indtil videre har et vist elskværdigt, konverserende præg. Vi har endnu til gode at se hvordan Chatman analytisk vil

10. Chatman spiller på Forsters kategorier »flad« og »rund« som indgang til en historisk skitse over karakterernes udvikling. Præ-moderne karakterer som eventyrfigurer, homeriske helte og riddere fra den høviske epik kan da ses som flade, dvs. uden psykologisk dybde, bundet til konventionelle dyder, roller og adfærd. Forbindelsen mellem karakter og handling er meget tæt, hvorfor det da også er sådanne karakterer der har inspireret til den formalistiske litteraturteori, hviket da igen er grunden til at den ikke lade sig applicere på moderne karakterer. Disse vil Chatman da karakterisere som »runde«i betydningen heterogene, flerfacettede, gådefulde. Der behøver ikke være nogen forbindelse til handling i umiddelbar forstand. Chatmans tanke har et eller andet for sig, men skal nok ikke strammes for meget. Dels er megen af den store realistiske moderne litteratur jo fyldt med både runde og flade karakterer, dels kan det store fokus på den problematiske karakter, anti-helten, i modernistisk litteratur (det som Northrop Frye har kaldt den ironiske modus: helten står lavere end forfatter og læser) ikke siges at være noget der befordrer karakterstudiet forstået som skabelsen af interessante og særegne karakterer 
forholde sig til karakterne, og om der i hans analytiske tilgang er impliceret en mere udfoldet ontologisk teori, der kan forklare deres store grad af autonomi.

En analytisk tilgang må have et både begrebsligt og håndtérligt udgangspunkt, og Chatman vælger her termen trait (da: træk, jvf. ansigtstræk, karaktertræk), som vi vil oversætte direkte til træk med den underforståede konnotation af karaktertræk. Et træk er navnet på den mindste væsentlige kvalitet eller egenskab ved en litterær karakter. Eller formuleret mere tekstuelt: et træk er et narrativt adjektiv, der knytter sig til et narrativt subjekt og som vil blive forstået - på det mimetiske niveau - som en egenskab ved en person. Det lyder ligetil. En litterær karakter møder vi jo som læsere gennem det teksten siger om ham - de prædikater, der knyttes til ham.

Allerede her er der dog visse problemer at tage højde for, påpeger Chatman. Der er f.eks. en nedre grænse for hvad der kan betragtes som træk: følelser, stemninger, tanker, midlertidige motiver og attituder, der i tekstens løb knyttes til personen behøver ikke være sammenfaldende med træk, selv om de kan være det. De kan f.eks. blot være betingede reflekser - at Pip i Store Forventninger bliver bange når han møder straffefangen eller tiltrukket, når han møder Estella. Ligeledes kan egenskaber, der fortjener navn af træk godt forsvinde og blive erstattet af andre, når karakteren udvikler sig: for igen at tage Pip som eksempel forsvinder hans skyhed og bliver erstattet af snobbethed for siden at blive erstattet af ydmyghed. Endelig bliver trækket ikke nødvendigvis meddelt, kommunikeret eller navngivet i i teksten; det kan være træk vi selv må slutte os til for at forstå hvad der foregår i teksten. Det vil f.eks. gælde alle de tekster, der har såkaldt "upålidelige fortællere« eller karakterer, der er hildet i et selvbedrag, som læseren selv skal slutte sig til.

Man må derfor sige, at det første indtryk af håndtérlighed ved træk-analysen snyder; det er ikke muligt på simpel vis at gå igennem teksten, tælle de træk man møder og lægge dem sammen til sidst. Alligevel er det som om Chatman spiller på en sådan forestilling. Han foreslår at man - metaforisk ser trækkene som et paradigme, en vertikal samling af træk, der skærer begivenhedernes syntagmatiske, dvs. forløbsmæssige, kæde. Forstået således at vi lærer en litterær karakter at kende ved at støde på - eller selv slutte os til - træk, som vi løbende anbringer i paradigmet. Når der hænder noget overraskende med karakteren, løber vi paradigmet igennem for at finde det træk, der forklarer det, og hvis vi ikke kan finde det, må vi konstruere et nyt og føje det til listen. Og dette er nok ikke så meget anderledes end hvad vi gør med folk i det virkelige liv, tilføjer han.

Det er de grammatiske begreber om syntagme og paradigme, og narratologiens begreb om det narrative forløb, der sammen udgør modellen for 
Chatmans træk-analytik. Men han er selv klar over forskellene. Til forskel fra det dagligsproglige paradigme, hvor det ord, der vælges, ikke »klinger af» alle de fravalgte, er det tilfældet her. Vi er så at sige nødt til at have hele paradigmet i bevidstheden, når vi vælger, men det styrker kun vores holistiske billede af karakteren. Til den narrative forløbsanalyse er der den afgørende forskel, at begivenheder har fikserede pladser i en historie, de efterfølger netop hinanden, begivenheder er diskrete entiteter, der støder op til hinanden. Trækkene har ikke den samme lineære og irreversible rækkefølge. Så snart de er genuine træk - og ikke forbigående stemninger - befinder de sig ikke i den temporale kæde (omend det er dér vi møder dem først); de sam-eksisterer med teksten i sin helhed, eller i hvert fald med dele af den.

Ved forsøgsvis at tage narratologien som en art model-teori for karakterologien, har Chatman fået demonstreret, at karakteren befinder sig på et andet niveau end handlingsgangen. Man kan med Per Krogh Hansen sige, at den ligger midtvejs mellem det narrative og det tematiske; den er ikke bundet til tekstens progression, selvom det er her den manifesterer sig, men på den anden side er den heller ikke statisk og uanskuelig som temaet.

Man må formode, at trækparadigmet oprettes præ-refleksivt i den spontane læsning, men spørgsmålet er så hvilket vokabularium man skal betjene sig af i den mere reflekterede læsning. Chatman henviser her relativt afslappet til dagligsproget, som er uendeligt righoldigt m.h.t. ord, der kan gælde som beskrivelse og benævnelser af karaktertræk. Den pris, der må betales for at gribe til dagligsproget, er så, at der ikke er tale om et begrebsapparat, der kan systematiseres og reduceres til semi-logiske enheder som i den narrative teori om »initiation", "sanktion« m.m. Men den pris må Chatman også være indforstået med at betale, fordi han på forhånd har benægtet muligheden af at moderne og runde karakterer kan reduceres til slet og ret funktioner og tekstuelle roller.

Målt med en meget metodebevidst alen må man indtil videre sige om Chatmans forslag til en karakteranalytik, at man med det i hånden ikke kan gå særligt præcist til værks (det er ikke nok at tælle og addere de træk, der står i teksten), og at man heller ikke har et præcist begrebsinventar til sin rådighed. Men det er en mangel på præcision, der afspejler reelle metodiske og principielle vanskeligheder. Dertil kommer spørgsmålet om karakterernes ontologi eller eksistensform, som Chatman ikke adresserer med lige disse ord, men som han alligevel begiver sig ind i nu.

Han griber til Forsters dinstinktion og betegner de flade karakterer som bærere af et teleologisk (formålsrettet) paradigme, de flade karakterer har kun ganske få træk eller ét meget dominerende, hvorfor de godt - sådan må vi udlægge det - kan reduceres til en rolle eller en funktion. Han anerkender med Forster at de derfor godt kan være meget levende men giver ikke rigtig 
et bud på hvorfor. Den runde karakters paradigme er derimod mere »klumpet sammen«, spredt og heterogent. Vi er mere intime med runde karakterer, selvom de ikke »summerer sig op« - de er open ended i deres konstruktion. Vi husker dem som om de var rigtige mennesker, men - som tilfældet også ofte er ved rigtige mennesker - kan vi have svært ved at huske pracist hvordan de er. Alligevel er de næsten uopslidelige genstande for vor fortsatte kontemplation; vores interesse for hvordan det siden gik dem, vores lyst til »sequels» er derfor ganske naturlig og legitim; den udspringer netop af at de er open ended.

Chatman er lidt vaklende her. Han betoner i radikal forstand de runde karakterers autonomi, men han har svært ved at forklare deres konstruktionsprincip udover at de er bunket sammen og uafsluttelige. Og ligesom Forster kommer han med den lidt underlige bemærkning om at de kan være svære at huske præcis, dvs. ud fra deres tekstuelle konstruktion. Men spørgsmålet er jo hvad der så giver dem den sluttehed og afrundethed, der gør at man alligevel kan huske dem. Og med hjælp af hvilke begrebslige værktøjer kan man indfange en karakters afgørende træk (individualiteten), det der gør den person identificérbar og forståelig hele vejen gennem teksten - som en enhed, der er i bevægelse og udsat for variationer? Dette er rundhedens gåde, for nu at bruger Forsters metafor.

Lad mig illustrere problemet gennem et klassisk eksempel, som Chatman også henviser til: A. C. Bradleys analyse af Shakespeares karakter Iago fra Othello. I 1904 skrev Bradley en bog, hvor han prøvede at analysere motiverne hos nogle af Shakespeares fremtrædende personer; f.eks. hvorfor handler Iago med denne ekstreme ondskab, og skubber Othello ud i en radikal jalousi og i mordet på hans elskede, Desdemona? Teksten giver ikke nogen egentlig grund til det, men Bradley følte sig forfulgt af spørgsmålet og blev således almindeligt til grin for megen moderne litteraturteori: se hvordan de gjorde dengang i de gamle, præ-videnskabelige dage! Iagos personlighed? Ha ha.

Bradley prøvede ud af de tekstuelle informationer at konstruere Iago som et helt menneske - lidt ligesom når en skuespiller i Stanislavski-traditionen, ud af sin egen erfaring og forestillingsevne, prøver at konstruere den person, som han skal spille, ud fra de få informationer som teksten giver. Som skuespiller kan man ikke forlade sig på at personificere enkelte træk som dukker op i teksten - man er nødt til at have, i hvert fald en slags skema for det menneske, der er bagved de ydre manifestationer i dialog, gestik, handlinger. ${ }^{11}$

Selvfølgelig kan man sige imod Bradley: spørgsmålet om Iagos personlighed er ikke relevant og lader sig ikke besvare. Jeg husker fra studietiden, at en af mine venner var stødt på det klassiske problem med Hamlets tøven, 
hvortil han sagde: det er absurd at opfatte Hamlet som en psykologisk entitet og udforske grundene til hans tøven. Hamlet tøver ikke - han tøves han er en agent, en tekstuel funktion, der bruges af en eller anden tekstuel instans, det være sig forfatteren, fortællefunktionen, plottet, diskursen, socialhistorien i mange mediationer, whatever. At behandle Hamlets motiver på den anden måde - ude af kontekst - giver simpelthen ikke mening.

Chatman synes imidlertid, at Bradleys analyse er legitim, lige så legitim som en nærlæsning. Og det stemmer også med de præmisser, han har opstillet: at karakteren ikke kun er hvad der står manifest i teksten, men også hvad man selv kan slutte sig til, og at karakteren er ko-eksisterende med teksten som en helhed - billedligt talt et implikationsrum man kan gå ind i og udforske.

Spørgsmålet er selvfølgelig hvad der så er det tekstlige korrelat for Bradleys konstruktion af Iagos personlighed. For her er det jo ikke tilstrækkeligt at tale om sammenbunkning og uafsluttethed. Bradley lægger jo ikke specifikke informationer sammen og tæller så op for at få et slutresultat. Han bevæger sig gennem de specifikke informationer for igennem dem at uddrage noget $\mathrm{i}$ en vis forstand endnu mere specifikt: Iagos uigentagelige individualitet. Så længe Iago bliver delt ud i enkelte træk og egenskaber, kan disse tillægges mange andre personer. Alligevel er der ingen andre personer, der er helt som Iago. Han er så at sige sit eget »begreb «. ${ }^{12}$

Dette spørgsmål om karakterens individualitet synes Chatman ikke at have noget bud på. Han afslutter sin tekst med nogle lidt modererende bemærkninger om at man selvfølgelig ikke skal overdrive det her med at betragte karakterer som levende mennesker; de har ikke et »liv« udenfor fiktionen, og selvom vi har ret til at bruge al vores menneskelige og kulturelle viden om personer i forhold til de litterære karakterer, er det nok ikke en god idé f.eks. at begynde at psykoanalysere dem (det kan nu være svært at se hvorfor dette er mindre legitimt end Bradley omend det sagtens kan være

11. Derfor er det ikke uden konsekvenser for litterær karakterologi om man inddrager dramaet i sine overvejelser eller ej. At holde dramaet ude af betragtning, som f.eks. Per Krogh Hansen gør, kan ikke undgå at favorisere et formalistisk syn på karakteren som alene »lavet af tekst«. Denne tilgang ville ikke lige så let kunne lade sig fastholde i forhold til dramaet. Man kan dertil indvende, at en scenisk realisering af et drama falder udenfor litteraturvidenskaben, der kun kan forholde sig til dramateksten. Men man kunne også sige, at en skuespiller blot skal »æse« dramaet på en særlig intens, forpligtet og konstruktiv måde; han skal konkretisere, udfylde en skematisk karakter, og det er til en vis grad sammenligneligt med hvad vi skal gøre som læsere af tekster.

12. Det er derfor berømte karakterer fra litteraturen kan opnå en symbolsk værdi næsten som om de var begreber og blive brugt som sådan: quixotesk, bovarysk osv. Men man kan ikke oversætte disse symbolers semantiske indhold på nogen simpel måde. Hvis en oversættelse skal have fylde, er man formentlig nødt til at give et mini-resumé af den tekst, de optræder i. 
mindre begavet). Og når vi bruger vores viden og begreber fra den virkelige verden, skulle vi måske huske at sætte nogle gåseøjne: Iago er ikke kold, han er »kold«.

Chatmans forsøg klinger således lidt svagt ud. Og jeg er ikke sikker på, at vi med denne atomistiske - ganske vist nuanceret og problembevidst - men dog atomistiske træk-for-træk tilgang kan forklare, hvorfor vi spontant giver ontologisk »kredit«til fiktive personer, og hvordan alle disse heterogene træk i et uafslutteligt paradigme på en eller anden måde kommer til at koagulere og danne den individuelle karakter.

En enkelt henvisning i teksten til en overvejelse af Roland Barthes peger dog i den retning: Barthes har funderet over egennavnets funktion i forhold til karakteren og foreslår at navnet er det, der muliggør at personen, dvs. den litterære karakter, kan eksistere $i$ sig selv udenfor de "semer«, hvis sum ikke desto mindre er det, der helt og holdent konstituerer personen. Navnet er dermed det, der i alle tilfælde og alt andet lige garanterer »identity" og »selfhood«. Dermed kan Chatman også løse problemet med hvordan der skal formidles mellem trækkenes uafsluttelighed og karakterens stabilitet: de endnu ikke benævnte træk hviler så at sige i egennavnet som et »restoplag«, der kan trækkes på.

Navnet er således den enkeltfaktor, der gør at personen vil fremtræde som en enhed ligegyldigt hvor uafsluttet og heterogen han så vil tage sig ud på det analytiske plan. Eller måske skal man bare sige benævnelsen. Chatman påpeger meget rigtigt, at også symbolske navne eller blotte deiktiske markeringer har den selvsamme funktion. ${ }^{13}$

Så snart der gives et Navn (selv i form af et pronomen) som noget kan flyde henimod og fæstne sig på, vil semerne blive prædikater, induktionspoler for sandhed (fiktionens sandhed, naturligvis), og Navnet vil blive et subjekt, hedder det hos Barthes.

Spørgsmålet er imidlertid om det ikke rejser nye problemer at løse sagen på denne måde. Om det ikke blot er en vikarierende løsning. For hvorfor er navne og pronomener egentlig så magtfulde og magiske og mystiske, at de kan oplyse og oplive en tekst indefra som små epifanier? Mon det ikke er fordi de henviser til den særlige type af genstande som vi kalder mennesker.

13. H. C. Branner har f.eks. en vane med at kalde sine personer for symbolsk farvede for ikke at sige symbolsk tyngede navne. Et rigtigt mandfolk hedder »Karl Svendsen« og i den dur. Men man kan konstatere, at det ikke har den ringeste effekt på funktionaliteten; karaktererne lever lige godt for det. Hvis jeg må tillade mig at henvise til min egen litterære produktion, så skrev jeg i drengeårene en serie sørøver-romaner, hvor en gennemgående figur i op til flere bind aldrig hed andet end "manden i laser og pjalter«. Jeg husker ikke mere om hans virkelige identitet tilsidst blev bragt for en dag, men jeg kan forsikre om at han ikke var den mindst interessante karakter i disse bind. 


\section{Solomon Asch - mennesker mødes og gestalter dannes}

Jeg vil nu vende mig mod Solomon Asch, en socialpsykolog, og hans teori om personlighed, eller rettere hans teori om hvordan vi strukturerer vore indtryk af personer, vi møder. Hvordan kommer vi til at opfatte et menneske som en distinkt psykologisk entitet? Hvordan udformer vi en kognitiv repræsentation af dette specifikke objekt - personen - i vor omgivelser? Dette er det emne Asch tager op i kapitlet »Knowledge of persons and groups« i Social Psychology, New York, 1953.

Hårdkogte tekstualister ville nok finde det temmelig irrelevant at inddrage vores opfattelse af virkelige personer i forbindelse med en diskussion af vor opfattelse af fiktive personer. Jeg mener til gengæld som tidligere nævnt, at man i praksis ikke kan diskutere litterære karakterer og litterær karakterologi uden under hånden at forudsætte en eller anden uekspliciteret opfattelse af virkelige karakterer. Alene for klarhedens og redelighedens skyld kan man derfor lige så godt indføre "virkelige personer« som en eksplicit kontrolgruppe. Med det mener jeg ikke at man skal indhente alle tænkelige og tilgængelige videnskabelige indsigter om mennesker for at kunne bedrive litterær karakterologi. Bl.a. fordi man jo ikke skal overdrive "substansen« af vores relation til virkelige personer. Også dér er der til en vis grad tale om at vi tilbydes spredte informationer, som vi efter bedste evne skal samle til en helhed. Vi skal da også netop se at Asch's undersøgelser kan omsættes temmelig ubesværet til vores karakterologiske diskussion.

Som en forløbig bemærkning erklærer Asch, at vi opfatter andre personers handlinger som virkninger og deres person(lighed) som årsagen. Hvis en person kommer regelmæssigt for sent til aftaler og ikke kan undskyldes af faktorer udenfor hans kontrol (forsinkede tog o.lign.) vil vi tilskrive ham denne kommen-for-sent som en permanent personlig egenskab. Hos den anden person kan vi iagttage mange forskellige handlinger og egenskaber i tilfældig rækkefølge; ikke desto mindre stræber vi altid efter at fatte den anden som en sammenhængende entitet. Og det er der forsåvidt ikke noget mystisk ved, kan vi tilføje for egen regning: vi har pragmatiske grunde til at gøre det - hvis vi vedvarende skal interagere med en anden person, er vi nødt til at opfatte ham som en enhed og ikke som et kaos af indtryk. Vi må danne os en forestilling om hvad vi kan »regne med«-og det er formentlig noget vi gør helt ubevidst. Dertil kan man tilføje at personen fremtræder jo ikke for os som et sansemæssigt kaos. Hans enhed er forudgivet, dels ved at han er fysisk stabiliseret (har en krop), dels ved at han er kulturelt stabiliseret (har et navn). Ovenpå disse to minima lejrer sig så en mængde signaler og informationer som vi skal forholde os til. Og det spørgsmål, vi skal for- 
følge med Asch, er efter hvilke principper former vi disse indtryk, former dem så de danner en karakterologisk enhed?

Man kan dermed sige, at på det analytiske niveau står vi i en position, der ikke er meget anderledes end litteraturlæserens eller Chatmans analytiker. Forskellen er dog, at personen er givet for os in the flesh. Vi behøver ikke at betvivle, at der er en sammenhængende person, en entitet, som indtrykkene lægger sig til.

Der er to synspunkter på hvordan vi former vores indtryk. Den første kalder Asch for den summative formulering: indtrykket af en person er summen af de karakteristika, vi har observeret hos ham: $a+b+c+d$ etc. Dette vil reducere indtrykket af enhed til et minimum. Den summative formulering bliver da heller ikke forsvaret af mange psykologer, påpeger Asch.

Han foretrækker selv det andet synspunkt, som han kalder Gestalt formuleringen: de egenskaber, vi bemærker, henter i stort omfang deres indhold fra deres indbyrdes lovmæssige forhold. Og det er deres interaktion, der konstituerer det enhedslige indtryk.

Asch refererer eksperimenter med grupper af personer, som skulle danne sig et indtryk, baseret på beskrivelse. Disse testpersoner havde rent faktisk hverken mødt eller set den person, som de skulle danne sig et indtryk af. I stedet blev de forelagt korte nedskrevne lister af egenskaber, og ud af dette materiale skulle de prøve at forestille sig yderligere egenskaber, vælge mellem forskellige forslag til supplerende egenskaber og danne sig et indtryk af personen som helhed. Man kan sige, at i en vis forstand er det proto-litteratur de præsenteres for og så meget bedre for vores formål.

To lister af egenskaber var de følgende, som kun adskiller sig på et enkelt punkt: intelligent - kompetent - flittig - varm/kold - beslutsom - praktisk - omhyggelig. Eksperimentet viste, at der var store forskelle på hvad de to testgrupper med hver sin liste kom op med. Forskellen mellem "varm« og »kold« havde med andre ord en betydelig indflydelse på det samlede indtryk. At udskifte én egenskab kan altså få en virkning på helheden, fordi denne enkelte term »farver« eller modificerer de andre egenskaber, omend ikke helt og holdent - de blev ikke alle påvirkede. Men det kunne tyde på, at visse egenskaber - eller »træk« - er centrale, andre er perifere.

Man kan bemærke sig, at de centrale karakteristika varm vs. kold også er de mest vage og metaforiske, man fristes til at sige tomme, på listen sammenlignet med de øvrige. Ikke desto mindre - eller måske netop derfor - bliver de forbundet med personen som et hele, hvor de andre ses som mere isolérbare egenskaber. En supplerende test, hvor de udskiftelige termer var høflig/direkte gjorde også en forskel i de to gruppers indtryk, men ikke så dramatisk som i tilfældet varm/kold. 
Det leder os til det naturlige spørgsmål om bestemte karakteristika altid er enten centrale eller perifere. Men det synes ikke at være tilfældet. »Varm» spillede en mindre dominerende og mindre favorabel rolle på den følgende liste: eftergivende - svag - overfladisk - varm - uambitiøs - forfængelig. Testpersonerne mente bl.a. at denne persons varme er den der strømmer fra en følgagtig person mod en leder, en hunde-agtig affektion, passiv og uden styrke.

Egenskabens indhold er tilsyneladende ikke givet én gang for alle, men kan veksle alt efter konteksten. På samme måde var »kold« hverken dominerende eller ufavorabel i den følgende sammenhæng: intelligent - kompetent oprigtig - kold - samvittighedsfuld - hjælpsom - beskeden. Egenskaben »kold« blev nu vurderet mere positivt end på den tidligere liste, fordi den blev perifer eller knyttet sammen med nogle andre, som alle er positive. Den kendsgerning, at en given egenskab ikke altid bærer på samme værdi eller betydning er et magtfuldt argument mod den summative formulering.

Det samme gælder et yderligere interessant aspekt, nemlig at den rækkefølge egenskaberne optræder i, spiller en vital rolle. I det virkelige liv opdager vi også en persons egenskaber i en temporal orden, og man kan forestille sig at udgangspunktet er afgørende: førstehåndsindtryk er en basis, og de senere opdukkende egenskaber bliver da modifikationer, korrektioner, af basis. I testen blev en person A beskrevet på følgende måde: intelligent - flittig - impulsiv - kritisk - stædig - misundelig. En person B blev beskrevet ud fra de samme egenskaber, men her i omvendt rækkefølge fra "misundelig« til »intelligent«. I A’s tilfælde præsenterer egenskaberne en rækkefølge fra det bedre til det værre. I B's tilfælde starter vi med det problematiske. Egenskaberne i midten af rækkefølgen er mere neutrale. Hvorom alting er, så blev A opfattet som en dygtig og tilforladelig person med visse mangler, mens B hovedsageligt blev set som et problem, til trods for visse talenter. Egenskaberne i midten kan falde til begge sider afhængige af retningen; hos A kan de opfattes som positive effekter af de indledende gode egenskaber: »Han er impulsiv, fordi han er intelligent. Han er kritisk, men det kan altså ikke undre nogen, når man både er intelligent og flittig«. I tilfældet B bliver de tilsvarende negative: „Han er kritisk fordi han er misundelig, og det er også derfor han ikke kan kontrollere sig selv og bliver impulsiv«. Den indledende term angiver således en retning, der indvirker på de efterfølgende. Selv to fuldstændig identiske serier af egenskaber kan altså give et forskelligt resultat, fordi det ikke er summen, men delenes interaktion - i dette tilfælde i henhold til rækkefølge - der producerer helheden, gestalten.

Den foregående liste blev på et tidspunkt splittet op i to A: intelligent flittig - impulsiv, og B: kritisk - stædig - misundelig. Testpersonerne skit- 
serede på baggrund af disse få træk to personer, og da de bagefter fik besked om at det var samme person, og at de nu skulle beskrive ham, var der flere der havde meget vanskeligt ved det p.g.a. de tidligere etablerede skikkelser og de endte med at beskrive en splittet person! Gestalten er med andre ord en magtfuld størrelse: den kan skitseres på baggrund af tre egenskaber og kan så være vanskelig at bryde totalt op igen!

Lad os opsummere: Ifølge Asch er det svært ikke at se et menneske som en enhed. Indtrykket stræber mod fuldstændighed, selv når oplysningerne er sparsomme. I det øjeblik vi har to eller flere egenskaber, der tilhører den samme person, træder de i dynamisk vekselvirkning med hinanden og mister derved deres isolerede og stabile indhold. Forskellige egenskaber har ikke samme vægt - nogle er centrale og styrende, andre bliver perifere og afhængige. Indtil vi har fundet "centrum«, føler vi ikke, at vi har nået en forståelse. Hvert træk er en del af et hele - når vi isolerer træk, har de derimod en tendens til at blive abstrakte som om de stod i en ordbog.

Dette implicerer også, at i en person fungerer enhver egenskab som repræsentativ for hele personen. Enhver egenskab borer hans saerlige signatur. A's charme er ikke den samme som B's charme. En person består således ikke af en individuel selektion af anonyme egenskaber, sådan som den summative formulering forestiller sig det. Og åbenlyse inkonsistenser mellem egenskaber vil altid få os til at søge efter et dybere niveau, der vil løse problemet.

Til sidst betoner Asch det, der ikke er blevet taget i betragtning i hans forsøg, men som ikke desto mindre er af stor betydning i møder i det virkelige liv. Test grupperne var neutrale iagttagere, men i det virkelige liv interagerer vi med de pågældende personer og vores indtryk vil også være afhængig af vore egne behov og krav i relationen og vor egen indre tilstand. A og B vil afvige fra hinanden i deres opfattelse af C, fordi de er forskellige fra hinanden. Med mindre man skal forestille sig at de ikke afviger så meget i beskrivelsen, som mere i hvad de lægger vægt på, hvilke træk de finder sym- og antipatiske. Og endelig er der ikke blevet sagt noget om sandhedsværdien af disse indtryk i henhold til deres genstand. Man kunne f.eks. forestille sig, at vi altid fejlbedømmer folk ved at søge - og "finde« - et samlende princip, der reelt ikke er til stede. Men det er ikke emnet her hvor spørgsmålet gjaldt hvordan vi danner os indtryk af personer.

\section{Afslutning}

Hvis man poder Aschs resultater på de karakterologiske diskussioner hos Forster og Chatman, vil en serie uløste problemer komme til at stå i et andet 
lys. Først og fremmest kan vi se, at den tekstuelle tilgang til de litterære karakterer, der implicerer, at karakteren ikke er et "noget« i sig selv, men blot summen af alt det teksten siger om »den«, svarer meget tydeligt til den summative formulering hos Asch. Men vi kunne jo formode, at vi som læsere »konstruerer« de litterære karakterer på samme måde som forsøgspersonerne konstruerede karaktererne, dvs. ikke summativt, men gestalt-mæssigt: på basis af selv meget få informationer, forestiller vi os en ganske bestemt og individuel entitet. Gestaltteorien, som udforsker helheder, der ikke kan reduceres til summen af deres elementer, kan derved give os det begrebslige værktøj, som den mimetiske tilgang til karakteren ellers har savnet.

Den flade karakter kan gestaltteoretisk defineres som en person, hvor et simpelt og tidligt fastlagt centrum fylder det hele: perifere egenskaber har næsten ingen betydning. Den runde karakter derimod skal aktivt formes af os; vi prøver at etablere en interaktion mellem forskellige egenskaber for at få et samlende indtryk. Denne drift mod enheden kunne udgøre en forklaring på metaforen rund, som ellers forekom at være en misvisende metafor for »kompleks«. Og man kunne forestille sig, at jo mere trækkene interagerer, jo mere synes karakteren at være »i live« som individ, fordi trækkene da ikke længere er isolerede entiteter, men bærer denne karakters særlige signatur. Vi ville her få en forklaring på hvorfor de store karakterer er lette at huske, men svære at beskrive - et paradoks som både Forster og Chatman er inde på. De er lette at huske qua gestalter (helheder, individualiteter) - men svære at beskrive qua summative træk (kombination af isolerede egenskaber). Det samme gælder i øvrigt i det virkelige liv, hvor vi som let som ingenting kan huske vores nære venner, men kan have svært ved at beskrive dem på en simpel måde overfor andre - eller acceptere andres forsimplede beskrivelse af dem - fordi vi kender dem som unikke gestalter.

Gestalten er det, der kommer til at tage sig mimetisk, »levende " og autonomt ud hos de runde karakterer, og det intrikate og besværlige forhold mellem det tekstuelle og det mimetiske hos både Forster og Chatman skyldes, at denne helhed ikke bare kan føres tilbage til at være summen af sine dele, hvilket ville være Chatmans teori om karakteren som et paradigme af træk.

En karakter er nemlig ikke en kombination af træk, hvis der dermed menes træk der eksisterer på forhånd og har en stabil mening som isolerede entiteter, der kan opsummeres. Eller rettere: den beskrivelse vil kun gælde for meget typificerede, flade karakterer, der har en stabil, konventionel betydning. Hvis vi skal fæstne lid til Asch og gestaltpsykologien, så foregår tingene for den runde karakter i omvendt orden: jo mere kompleks karakteriseringen viser sig at være, jo mere mister trækkene deres "abstrakte» betydning og begynder at modificere hinanden. Og jo længere vi kommer 
mod karakterens individualitet, jo mere vil denne individualitet blive det organisatoriske centrum for trækkenes betydning. Hvert træk bærer karakterens signatur.

I den forstand kunne Bradleys konstruktion af Iago (i princippet, jeg vil ikke kommentere på den i detaljer) med sin »opadgående strukturering« ses som en eksemplarisk model for litterær karakterologi. Jo længere frem vi kommer i karakteriseringsprocessen, jo mere futilt vil det være at appellere til hvad teksten selv siger i den simple betydning af ordet, sådan som Bradleys kritikere gjorde.

Forster og Chatman viser på hver deres måde, hvor svært det er at angribe karakter-problemet fra den tekstuelle side, dvs. uden at have øje for gestaltningens særlige dynamik. Forster har et udestående med »det levende«, både de flade karakterers forbløffende liv, og de runde karakterer som er rede til et udvidet liv - de første virker ikke som de konstrukter de er, de sidste virker ikke så tekst-dependente som de er. Chatman kan ikke forklare hvordan trækkene kan koagulere til en personlighed, eller rettere, han må gribe til den vikarierende løsning omkring benævnelsen: navnet som en art pose eller beholder, trækkene kan puttes ned i og holdes sammen af.

Måske kunne man løse Forsters problem om modsætningen mellem det dependente og det autonome ved at sige at det er en falsk modstilling: jo bedre karakteren er lavet, jo mere enhedslig (rund, gestaltagtig) bliver han, og jo lettere er han dermed også at autonomisere, huske, forestille sig i andre værker, føle som levende. I modsætning til de personer, der ikke er godt nok lavet og dermed aldrig kommer til at »løfte sig« - og heller ikke har karikaturens, den flade karakters, tydeliggørelse at falde tilbage på. Gestalten vil da være en slags en emergens-effekt, og når den først er indtrådt, er autonomiseringen sket, og så kan man ikke længere - som udtømmende forklaring føre karakteren tilbage til dens bestanddele længere. Men derfor er de der jo alligevel endnu. Tekstualismen vil derfor stadig kunne give mange legitime bud på karakterernes analytik - hvordan og af hvad de er lavet - men kan ikke råde for karakterernes ontologi - deres liv, deres autonomi, deres individualitet, deres mimesis.

Det, som tekstualismen, når den er bedst, vil kunne levere, vil ikke nødvendigvis have meget med Chatmans træk-paradigme at gøre. Man vil snarere skulle se på helt andre elementer af tekstteorien og -analysen, f.eks. nogle af de »dybdestrukturer«, Per Krogh Hansen har fremhævet: værdisystemer og paradigmer, udsigelse og fortællersynsvinkel, tematiske strukturer m.m. Og den mimetiske tilgang vil blive udfordret i det omfang tekstualisten måtte kunne sandsynliggøre, at karakteren faktisk er definitivt analysérbar, også i betydningen »opløselig«, i forhold til sådanne strukturer. 
Den gestaltteoretiske tilgang skal ikke forstås på en semi-mystisk måde: at på en uforudsigelig tærskel af træk - voosh - går det summative over i gestaltform - næsten som når man skifter til warp speed i rumfilm. Asch's undersøgelse viser, at gestalt-effekten kan indtræde ved meget få egenskaber - og det modsvares af vores erfaring med at læse litteratur, hvor vi jo ikke først "regner« med personerne og giver dem ontologisk kredit, når vi har hørt meget om dem. Man skal bare lige nævne "manden i laser og pjalter«så sidder den der. ${ }^{14}$ Navnet eller benævnelsen må anskues som en stand in for gestalten, hvorfor Barthes' mere radikale antagelse af at det er navnet $i$ sig selv, der sikrer karakteren en art på skrømt-eksistens ikke holder.

Men hvad er præcist forbindelsen mellem den gestaltteoretiske reformulering af karakteren og den mimetiske forestilling om karakteren som »levende« og menneske-lig? Hvorfor kan man ikke blot tage gestaltteorien til sig som en raffinering af en tekstuel karaktertilgang - gestalt forstået som en dynamisk struktur i teksten? ${ }^{15}$ Det kan man ikke, fordi det for mig at se må ligge implicit i den formalistiske eller tekstuelle tilgang, at helheden, gestalten, altid kan tilbageføres til eller analyseres (skilles ad) i sine tekstlige bestanddele. Men dermed er det også kun en på skrømt-gestalt. Omvendt må definitionen på »liv« i karakterologisk forstand netop være at karakterens præg af konstruerethed/kunstighed forsvinder (jvf. de slet formede karakterer, der ikke bliver »levende«), ikke blot i den svage forstand, at læseren glemmer det eller overser det p.g.a. forfatterens behændighed og kunnen, men i den stærke forstand, at karakteren i sidste ende er en afgrænset entitet, der i sin yderste konsekvens kun lader sig analysere på sine egne individuelle præmisser.

Men hvis vi medgiver det - at karakteren på en måde hæver sig op over sin afhængighed af teksten, hvilket vi metaforisk kan kalde for at den bliver »levende» - hvad er det så der yderligere begrunder, at dette »liv« kan repræsentere det rigtige levede liv? Ja, med baggrund i Asch kan man sige, at litterære personer er givet for os på en måde, der er analog til virkelige personer (bortset fra at de er ikke givet for os fysisk og at vi kan ikke interagere

14. Formentlig er det også denne gestalt-effekt, Forster er på sporet af i sine lidt uldne betragtninger om forklarligheden som det artsspecifikke ved homo fictus til forskel fra homo sapiens. Det afgørende er som nævnt ikke om karakteren bliver forklaret eller ej - hvilket ville åbne Forsters synspunkt for en stilhistorisk kritik (»hvad så med alle de dunkle og fragmentariske karakterer i moderne litteratur? «) - men at man har følelsen af at det kan den blive, dvs. at den litterære karakter ikke som det virkelige menneske er bundet til at være givet for os i en perspektivisk forkortning, men potentielt går mod uendeligt i gestaltningsdynamikken.

15. Det er f.eks. det Per Krogh Hansen gør i Karakterens rolle p. 140 ff. hvor han har ladet sig inspirere af min brug af Solomon Asch i den oprindelige version af denne artikel, jvf. note 1. 
med dem). Men når det kommer til den konkrete litterære tekst - og anden litteratur findes jo ikke - er det vores egen vurdering, der afgør om "livet« i dette konkrete tilfælde repræsenterer livet. Der er i hvert fald ikke noget teoretisk og principielt gangbart argument (tekstualismen) imod at det skulle kunne være tilfældet. 